\title{
Confirmation of Thiomonas delicata (formerly Thiobacillus delicatus) as a distinct species of the genus Thiomonas Moreira and Amils 1997 with comments on some species currently assigned to the genus
}

Correspondence

Donovan P. Kelly

D.P.Kelly@warwick.ac.uk

\author{
Yoko Katayama, ${ }^{1}$ Yoshihito Uchino, ${ }^{2}$ Ann P. Wood ${ }^{3}$ and Donovan P. Kelly ${ }^{4}$ \\ ${ }^{1}$ Department of Environmental and Natural Resource Science, Graduate School of Agriculture, \\ Tokyo University of Agriculture and Technology, Fuchu, Tokyo 183-8509, Japan \\ ${ }^{2}$ NITE Biological Resource Center, National Institute of Technology and Evaluation, \\ 2-5-8 Kazusakamatari, Kisarazu-shi, Chiba 292-0818, Japan \\ ${ }^{3}$ Department of Microbiology, King's College London Dental Institute at Guy's, King's College \\ and St Thomas' Hospitals, Floor 28 Guy's Tower, Guy's Campus, London SE1 9RT, UK \\ ${ }^{4}$ Department of Biological Sciences, University of Warwick, Coventry CV4 7AL, UK
}

The genus Thiomonas was established by David Moreira and Ricardo Amils to comprise four species of chemolithotrophic autotrophs that formed a phylogenetic cluster within the $\beta$-1 subgroup of the Betaproteobacteria (Moreira \& Amils, 1997). All four species (Thiomonas intermedia, Thiomonas perometabolis, Thiomonas thermosulfata and Thiomonas cuprina) were previously assigned to Thiobacillus but were found, by comparison of $5 \mathrm{~S}$ and $16 \mathrm{~S}$ rRNA gene sequences and by restriction fragment length analysis, to be rather remote from members of that genus (Moreira \& Amils, 1997). Their closest phylogenetic neighbours within Thiobacillus were Thiobacillus thioparus and Thiobacillus denitrificans, which are in the $\beta$-2 subgroup of the Betaproteobacteria (Lane et al., 1992). The 16S rRNA gene sequence similarity between Thiobacillus thioparus and Thiomonas intermedia was only $87 \%$. Additional defining characteristics of the four Thiomonas species included the $\mathrm{G}+\mathrm{C}$ content of their DNA being between 61 and $69 \mathrm{~mol} \%$, the presence of ubiquinone Q-8, the inability to denitrify nitrate to dinitrogen and optimum growth as mixotrophs when supplied with both a reduced inorganic sulfur compound and a variety of organic substrates, but the ability also to grow chemolithoautotrophically or as chemoorganotrophs (Katayama-Fujimura et al., 1982, 1984; Moreira \& Amils, 1997).

The GenBank/EMBL/DDBJ accession number for the 16S rRNA gene sequence of Thiomonas delicata NBRC $14566^{\top}$ is AB245481.
Moreira \& Amils (1997) did not include Thiobacillus delicatus in the new genus as Thiomonas delicata, as insufficient phylogenetic data were then available, but they indicated that its affiliation with this mixotrophic group needed further investigation. Thiobacillus delicatus was originally isolated and characterized about 30 years ago (Mizoguchi et al., 1976; Katayama-Fujimura et al., 1982) and the name was formally revived with an emended species description by Katayama-Fujimura et al. (1984). It was retained in the list of species of the genus Thiobacillus in the 1989 and 2005 editions of Bergey's Manual of Systematic Bacteriology (Kelly \& Harrison, 1989; Kelly et al., 2005). However, Kelly \& Wood (2005) proposed that Thiobacillus delicatus should also be transferred to the genus Thiomonas as Thiomonas delicata, on the basis of its physiological and biochemical properties (Table 1), subject to its phylogenetic relationship being confirmed by $16 \mathrm{~S}$ rRNA gene sequencing (Kelly et al., 2005; Kelly \& Wood, 2005). This has now been done and we report that Thiobacillus delicatus should henceforth be known as Thiomonas delicata (Kelly \& Wood, 2005, 2006).

A nearly complete $16 \mathrm{~S}$ rRNA gene sequence (1456 nucleotides) of Thiomonas delicata strain THI $091^{\mathrm{T}}$ (NBRC $14566^{\mathrm{T}}$ ) was determined at the NITE Biological Resource Center (NBRC) and was deposited with GenBank/EMBL/ DDBJ, under accession number AB245481. The sequence shared $93.4 \%$ similarity with that of the type species, Thiomonas intermedia (Table 1). Comparison with database 
Table 1. Comparison of Thiomonas delicata NBRC $14566^{\top}$ with the type strains of other species of Thiomonas

Strains: 1, Thiomonas delicata NBRC $14566^{\mathrm{T}}$; 2, 'Thiomonas arsenivorans' DSM 16361; 3, Thiomonas intermedia ATCC 15466 ${ }^{\mathrm{T}}$; 4, Thiomonas perometabolis ATCC $23370^{\mathrm{T}}$; 5 , Thiomonas thermosulfata ATCC $51520^{\mathrm{T}}$; 6, Thiomonas cuprina DSM $5495^{\mathrm{T}}$. Data were obtained from the present study and from London (1963), London \& Rittenburg (1967), Mizoguchi et al. (1976), Huber \& Stetter (1990), Katayama-Fujimura \& Kuraishi (1983), Katayama-Fujimura et al. (1982, 1984), Kelly \& Harrison (1989), Shooner et al. (1996), Moreira \& Amils (1997), Battaglia-Brunet et al. (2006), Kelly \& Wood (2005) and Kelly et al. (2005). NA, Data not available in the literature.

\begin{tabular}{|c|c|c|c|c|c|c|}
\hline Characteristic & 1 & 2 & 3 & 4 & 5 & 6 \\
\hline DNA G $+\mathrm{C}$ content $(\mathrm{mol} \%)^{\star}$ & $66-67^{a, b}$ & $65^{c}$ & $65-67^{a}$ & $65-66^{a}$ & $61^{d}$ & $66-69^{a, c}$ \\
\hline 16S rRNA gene sequence similarity with Thiomonas intermedia (\%) & $93 \cdot 4$ & $93 \cdot 5$ & $(100)$ & $99 \cdot 7$ & $94 \cdot 1$ & $87 \cdot 3$ \\
\hline DNA-DNA hybridization with Thiomonas intermedia DNA (\%) & $25-28$ & 49 & $(100)$ & $31-35$ & NA & NA \\
\hline Cell width $(\mu \mathrm{m})$ & $0 \cdot 4-0 \cdot 6$ & $0 \cdot 3-0 \cdot 5$ & $0 \cdot 6-0 \cdot 8$ & $0 \cdot 4-0 \cdot 5$ & $0 \cdot 9$ & $0 \cdot 3-0 \cdot 5$ \\
\hline Cell length $(\mu \mathrm{m})$ & $1 \cdot 0-1 \cdot 6$ & $1 \cdot 0-2 \cdot 0$ & $1 \cdot 0-1 \cdot 4$ & $1 \cdot 1-1 \cdot 7$ & $1 \cdot 3-2 \cdot 3$ & $1 \cdot 0-4 \cdot 0$ \\
\hline Motility & - & + & + & + & + & + \\
\hline Flagellation & - & + & Polar & Polar & + & + \\
\hline Ubiquinone & Q-8 & NA & Q-8 & Q-8 & Q-8 & Q-8 \\
\hline \multicolumn{7}{|l|}{ Major cellular fatty acids: $\dagger$} \\
\hline 3-Hydroxydecanoic acid & + & NA & + & + & NA & NA \\
\hline 3-Hydroxy-8-methylnonanoic acid & + & $\mathrm{NA}$ & - & + & NA & NA \\
\hline 3-Hydroxydodecanoic acid & - & NA & + & + & NA & NA \\
\hline \multicolumn{7}{|l|}{ Growth on/oxidation of: } \\
\hline Thiosulfate & + & + & + & + & + & - \\
\hline Tetrathionate & + & + & + & + & + & - \\
\hline $\mathrm{Fe}(\mathrm{II})$ & $\mathrm{NA}$ & + & - & - & - & - \\
\hline Arsenite & NA & + & + & - & NA & NA \\
\hline Transitory formation of polythionates during thiosulfate oxidation & + & NA & - & - & + & - \\
\hline Chemo-organotrophic growth with single organic compounds & - & + & - & + & $+1-\ddagger$ & $+1-\$$ \\
\hline Nitrate reduction to nitrite & + & - & - & - & - & - \\
\hline Optimum pH & $5 \cdot 5-6 \cdot 0$ & $4 \cdot 0-7 \cdot 5$ & $5 \cdot 5-6 \cdot 0$ & $5 \cdot 5-6 \cdot 0$ & $5 \cdot 2-5 \cdot 6$ & $3 \cdot 0-4 \cdot 0$ \\
\hline $\mathrm{pH}$ limits for growth & $5 \cdot 0-7 \cdot 0$ & $2 \cdot 5-8 \cdot 0$ & $5 \cdot 0-7 \cdot 0$ & $5 \cdot 0-7 \cdot 0$ & $4 \cdot 3-7 \cdot 8$ & $2 \cdot 0-6 \cdot 5$ \\
\hline Optimum temperature $\left({ }^{\circ} \mathrm{C}\right)$ & $30-35$ & $20-30$ & $30-35$ & $35-37$ & $50-53$ & $30-36$ \\
\hline Temperature limits for growth $\left({ }^{\circ} \mathrm{C}\right) \|$ & $15-42^{a}$ & 4 to $<45^{b}$ & $15-37$ & $15-42$ & $34-65$ & $-^{c}$ \\
\hline
\end{tabular}

${ }^{\star} \mathrm{G}+\mathrm{C}$ values were determined by using the following methods: ${ }^{a}$ thermal denaturation $\left(T_{\mathrm{m}}\right)$; ${ }^{b}$ chemical analysis after hydrolysis with perchloric acid; ${ }^{c}$ HPLC after enzymic digestion; ${ }^{d}$ UV ratios (Ulitzur, 1972).

$\dagger$ Thiomonas delicata, Thiomonas intermedia and Thiomonas perometabolis contain hexadecanoic acid, hexadecenoic acid plus $\mathrm{C}_{17}$ cyclopropane acid, and octadecenoic acid plus $\mathrm{C}_{19}$ cyclopropane acid. NA for the other species.

¥Growth with succinate or glutamate.

§Growth with pyruvate.

$\|^{a} \mathrm{No}$ growth at 10 or $45^{\circ} \mathrm{C}$; ${ }^{b}$ weak growth at $4{ }^{\circ} \mathrm{C}$, but no growth at $45^{\circ} \mathrm{C}$; ${ }^{\circ}$ No growth at 15 or $50^{\circ} \mathrm{C}$.

sequences for other Thiomonas species using the BLAST algorithm (http://www.ncbi.nlm.nih.gov/blast/; Altschul et al., 1997) showed $99.9 \%$ similarity of the Thiomonas delicata sequence with that of 'Thiomonas arsenivorans' (Battaglia-Brunet et al., 2006) and with those of Thiomonas sp. strain RCASK1 (AJ879998), Thiomonas sp. C19 (AF460989) and Thiomonas sp. CO2 (AF460988), with similarities of $93.4 \%$ with Thiomonas intermedia and Thiomonas perometabolis, $91 \cdot 1 \%$ with Thiomonas thermosulfata and $88 \cdot 8 \%$ with Thiomonas cuprina (Fig. 1).

The 16S rRNA gene sequence of Thiomonas delicata differs from that of 'Thiomonas arsenivorans' and several other database sequences of Thiomonas spp. by only one to three nucleotides, but Thiomonas delicata and 'Thiomonas arsenivorans' are distinguished from each other by a number of physiological and biochemical characteristics (Table 1). In particular, Thiomonas delicata has the following properties that are not shared with 'Thiomonas arsenivorans': it is non-motile, has more restricted ranges of temperature and $\mathrm{pH}$ for growth and optimum growth, can grow as an anaerobe using nitrate reduction to nitrite, but does not show heterotrophic growth on single organic compounds (glucose, fructose, ethanol, propanol, glycerol, oxalate, gluconate, pyruvate, lactate, malate, succinate, 2oxoglutarate, citrate, alanine, serine, aspartate, glutamate, proline and histidine). Whereas 'Thiomonas arsenivorans' grows autotrophically on arsenite and chemo-organotrophically on a wide range of organic acids and sugars (Battaglia-Brunet et al., 2006), best growth of Thiomonas 


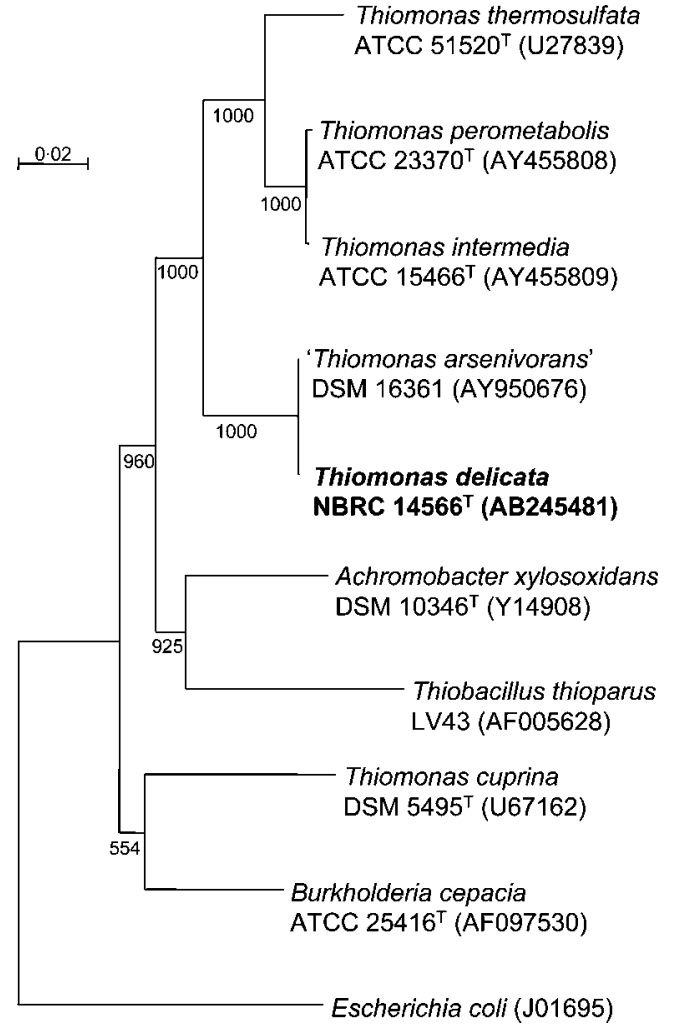

Fig. 1. Phylogenetic tree based on $16 \mathrm{~S}$ rRNA gene sequences showing the relationship of Thiomonas delicata NBRC $14566^{\top}$ to the other four recognized species of Thiomonas and 'Thiomonas arsenivorans'. The analyses were performed using the neighbour-joining CLUSTAL $X$ (version 1.82) method (Jeanmougin et al., 1998) and evolutionary distances calculated by using the Kimura two-parameter procedure (Kimura, 1980). Escherichia coli (Gammaproteobacteria) was included as an outgroup. Bar, $2 \%$ nucleotide divergence. Numbers at nodes are bootstrap values from 1000 subsamples.

delicata is obtained on mixotrophic media with thiosulfate supplemented with Krebs cycle intermediates or amino acids. Optimal growth as a mixotroph is a property reportedly shared with Thiomonas intermedia, Thiomonas perometabolis, Thiomonas thermosulfata and Thiomonas cuprina (Moreira \& Amils, 1997; Kelly \& Wood, 2005). Whereas 'Thiomonas arsenivorans' can grow well on yeast extract, Thiomonas delicata gave virtually no growth with $0 \cdot 1 \%(\mathrm{w} / \mathrm{v})$ yeast extract alone (about $5 \mathrm{mg}$ cell protein $\left.1^{-1}\right)$, but supplementing with $0.5 \%(\mathrm{w} / \mathrm{v})$ thiosulfate increased the biomass production to $90 \mathrm{mg}$ cell protein $1^{-1}$, compared with about $40 \mathrm{mg}$ cell protein $1^{-1}$ with thiosulfate alone (Mizoguchi et al., 1976). With $0 \cdot 5 \%(\mathrm{w} / \mathrm{v})$ yeast extract, the biomass production was stimulated to about sixfold over that with thiosulfate alone (KatayamaFujimura et al., 1984). While these properties suggest that Thiomonas delicata and 'Thiomonas arsenivorans' are separate species, determination of the ability of Thiomonas delicata to oxidize $\mathrm{Fe}(\mathrm{II})$ and $\mathrm{As}(\mathrm{III})$ and DNA-DNA hybridization between them will help to establish whether 'Thiomonas arsenivorans' is a distinct species or a subspecies of Thiomonas delicata. In this respect, it is noteworthy that the 16S rRNA gene sequences of Thiomonas intermedia and Thiomonas perometabolis also differ by only four nucleotides ( $99.7 \%$ similarity), but were shown by DNA-DNA hybridization, 23S rRNA gene and restriction fragment length polymorphism to be distinct species (KatayamaFujimura et al., 1982; Kelly \& Harrison, 1989; Moreira \& Amils, 1997).

The name Thiomonas delicata (Kelly \& Wood, 2006) will have taxonomic precedence when validating the names of existing and future isolates of Thiomonas that are indistinguishable from it on the basis of their 16S rRNA gene sequences. Such isolates will require assessment of their physiological characteristics and comparative DNA-DNA hybridization with Thiomonas delicata. In this respect, there are numerous examples of species, in some cases from the same habitats, which share virtually identical 16S rRNA gene sequences (99-100\%) but show only $0-35 \%$ interspecies DNA-DNA hybridization (Ash et al., 1991; Fox et al., 1992; Martinez-Murcia et al., 1992; Jaspers \& Overmann, 2004).

Thiomonas species can also exhibit extremely divergent $16 \mathrm{~S}$ rRNA gene sequences, as is seen with Thiomonas cuprina, which shows only $85 \cdot 9-88 \cdot 8 \%$ sequence similarity with the other four Thiomonas species with validly published names. All five species have a rather distant relationship with strains of the $\beta-1$ betaproteobacterium Burkholderia cepacia (87-90\% similarity) but, apart from Thiomonas cuprina, they show $91 \cdot 1-99 \cdot 7 \%$ similarity with each other. On the basis of physiological properties and molecular analyses, Moreira \& Amils (1997) argued that Thiomonas cuprina should be included in the genus Thiomonas. However, the current wealth of betaproteobacterial 16S RNA gene sequences indicates that Thiomonas cuprina is not securely placed as a recognized member of the Thiomonas clade on phylogenetic trees, being at least as closely related to $B$. cepacia and some other genera as to the Thiomonas cluster (Fig. 1; Y. Uchino, additional data not shown). None of the recognized species (or 'Thiomonas arsenivorans'), except Thiomonas cuprina, has been reported to be capable of autotrophic growth on sulfide minerals. Moreira \& Amils (1997) erroneously stated that Thiomonas cuprina also could not grow on sulfide minerals, but the type strain grew autotrophically on arsenopyrite, chalcopyrite, galena, cadmium sulfide and synthetic FeS (Huber \& Stetter, 1990), although it did not oxidize Fe(II). In contrast to the other species of Thiomonas described to date, it could not grow on thiosulfate or tetrathionate as energy substrates, being able to use only more reduced sulfur substrates such as elemental sulfur and sulfides. With the exception of 'Thiobacillus plumbophilus' (Drobner et al., 1992), this inability to use thiosulfate is unique among all the species currently and previously known as Thiobacillus (Kelly \& Harrison, 1989; Kelly et al., 2005) and other chemolithotrophic thiosulfate-oxidizing Proteobacteria such as 
Paracoccus, Pseudaminobacter and Thiomicrospira. However, Thiomonas cuprina and 'Thiobacillus plumbophilus' are not closely related phylogenetically, as they show insignificant DNA-DNA hybridization (Drobner et al., 1992) and share only about $85 \% 16 \mathrm{~S}$ rRNA gene sequence similarity (estimated by BLAST 2 sequence comparison). Also, contrary to the description of Thiomonas cuprina provided by Moreira \& Amils (1997), Huber \& Stetter (1990) did not report that this species grew best under mixotrophic conditions. Unlike other Thiomonas species, the type strain of Thiomonas cuprina is moderately acidophilic with some strains being extreme acidophiles (Huber \& Stetter, 1990). As well as sharing only $86-89 \% 16$ S rRNA gene sequence similarity with the other Thiomonas species, Thiomonas cuprina shows only $85-89 \%$ sequence similarity with other phylogenetically related Betaproteobacteria, including the type strains of B. cepacia, Leptothrix discophora and Comamonas testosteroni. Thiomonas cuprina also shares $87 \cdot 5 \%$ similarity of its $23 \mathrm{~S}$ rRNA gene sequence with that of B. cepacia (Moreira \& Amils, 1996). Currently, Thiomonas cuprina appears to have no closer phylogenetic neighbours than these genera (Moreira \& Amils, 1997; D. P. Kelly, unpublished sequence analyses). It clearly differs from $B$. cepacia at the genus level (Selenska-Pobell et al., 1998). There is thus a case for considering the promotion of Thiomonas cuprina as representing a novel genus of moderately acidophilic, metal sulfide-oxidizing, facultatively chemolithoautotrophic Betaproteobacteria.

The description of Thiomonas delicata is essentially that provisionally proposed by Kelly \& Wood (2005), based on that of Katayama-Fujimura et al. (1984), as emended below. The type strain is available from the NBRC (Japan), the Korean Collection of Type Cultures (KCTC) and the DSMZ.

\section{Emended description of Thiomonas delicata (Katayama-Fujimura et al. 1984) Kelly and Wood 2006}

Thiomonas delicata (del.i.cat' a. L. fem. adj. delicata delicate).

Basonym: Thiobacillus delicatus (ex Mizoguchi et al. 1976) Katayama-Fujimura et al. 1984.

Rods, usually single, rarely in pairs, $0 \cdot 4-0 \cdot 6 \mu \mathrm{m}$ wide and $1 \cdot 0-1 \cdot 6 \mu \mathrm{m}$ long. Non-motile. Colonies grown on yeast extract-thiosulfate agar $(1 \mathrm{~mm}$ in diameter) are smooth and circular and change from transparent to whitish-yellow with sulfur. Facultative chemolithotroph and mixotroph. Grows autotrophically with sulfur, thiosulfate and tetrathionate, but not with thiocyanate; accumulates tetrathionate and trithionate transiently during growth on thiosulfate. Incapable of chemo-organotrophic growth on single carbon compounds. Grows mixotrophically with thiosulfate as an energy source in mineral media supplemented with tricarboxylic acid cycle intermediates, amino acids or yeast extract. Optimum growth requires both organic substances and thiosulfate or sulfur. Facultative anaerobe; reduces nitrate and produces nitrite in mixotrophic and autotrophic media with thiosulfate or tetrathionate, but does not denitrify nitrate to nitrogen gas. Ammonium salts, nitrate, urea, glutamate or aspartate can be used as a nitrogen source. Optimum temperature, $30-35^{\circ} \mathrm{C}$; growth range, $15-42{ }^{\circ} \mathrm{C}$ (no growth at 10 or $45^{\circ} \mathrm{C}$ ). Optimum pH, 5·5-6.0; growth range, $\mathrm{pH} 5 \cdot 0-7 \cdot 0$. Isolated from mine water. Distribution unknown. The $\mathrm{G}+\mathrm{C}$ content of the DNA is 66-67 mol\% ( $T_{\mathrm{m}}$, chemical analysis).

The type strain is THI $091^{\mathrm{T}}$ [ $=$ NBRC $14566^{\mathrm{T}}$ (formerly IFO $\left.14566^{\mathrm{T}}\right)=$ KCTC $2851^{\mathrm{T}}=$ DSM $17897^{\mathrm{T}}$ ]. The culture deposited as IAM $12624^{\mathrm{T}}$ is no longer available from that collection.

\section{Acknowledgements}

We thank Fabienne Battaglia-Brunet for providing data on 'Thiomonas arsenivorans' prior to publication.

\section{References}

Altschul, S. F., Madden, T. L., Schäffer, A. A., Zhang, J., Zhang, Z., Miller, W. \& Lipman, D. J. (1997). Gapped BLAST and PSI-BLAST: a new generation of protein database search programs. Nucleic Acids Res 25, 3389-3402.

Ash, C., Farrow, J. A. E., Dorsch, M., Stackebrandt, E. \& Collins, M. D. (1991). Comparative analysis of Bacillus anthracis, Bacillus cereus, and related species on the basis of reverse transcriptase sequencing of $16 \mathrm{~S}$ rRNA. Int J Syst Bacteriol 41, 343-346.

Battaglia-Brunet, F., Joulian, C., Garrido, F., Dictor, M.-C., Morin, D., Coupland, K., Johnson, D. B., Hallberg, K. B. \& Baranger, P. (2006). Oxidation of arsenite by Thiomonas strains and characterization of Thiomonas arsenivorans sp. nov. Antonie van Leeuwenhoek 89, 99-108.

Drobner, E., Huber, H., Rachel, R. \& Stetter, K. O. (1992). Thiobacillus plumbophilus spec. nov., a novel galena and hydrogen oxidizer. Arch Microbiol 157, 213-217.

Fox, G. E., Wisotzkey, J. D. \& Jurtshuk, P., Jr (1992). How close is close: $16 \mathrm{~S}$ rRNA sequence identity may not be sufficient to guarantee species identity. Int J Syst Bacteriol 42, 166-170.

Huber, H. \& Stetter, K. O. (1990). Thiobacillus cuprinus sp. nov., a novel facultatively organotrophic metal-mobilizing bacterium. Appl Environ Microbiol 56, 315-322.

Jaspers, E. \& Overmann, J. (2004). Ecological significance of microdiversity: identical $16 \mathrm{~S}$ rRNA gene sequences can be found in bacteria with highly divergent genomes and ecophysiologies. Appl Environ Microbiol 70, 4831-4839.

Jeanmougin, F., Thompson, J. D., Gouy, M., Higgins, D. G. \& Gibson, T. J. (1998). Multiple sequence alignment with CLUSTAL X. Trends Biochem Sci 23, 403-405.

Katayama-Fujimura, Y. \& Kuraishi, H. (1983). Emendation of Thiobacillus perometabolis London and Rittenberg 1967. Int J Syst Bacteriol 33, 650-651.

Katayama-Fujimura, Y., Enokizono, Y., Kaneko, T. \& Kuraishi, H. (1982). Deoxyribonucleic acid homologies among species of the genus Thiobacillus. J Gen Appl Microbiol 29, 287-295.

Katayama-Fujimura, Y., Kawashima, I., Tsuzaki, N. \& Kuraishi, H. (1984). Physiological characteristics of the facultatively chemolithotrophic Thiobacillus species Thiobacillus delicatus nom. rev., emend., Thiobacillus perometabolis, and Thiobacillus intermedius. Int J Syst Bacteriol 34, 139-144. 
Kelly, D. P. \& Harrison, A. P. (1989). Genus Thiobacillus Beijerinck $1904 \mathrm{~b}, 597^{\mathrm{AL}}$. In Bergey's Manual of Systematic Bacteriology, 1st edn, vol. 3, pp. 1842-1858. Edited by J. T. Staley, M. P. Bryant, N. Pfennig \& J. G. Holt. Baltimore: Williams \& Wilkins.

Kelly, D. P. \& Wood, A. P. (2005). Genus Incertae Sedis XVIII. Thiomonas Moreira and Amils 1997, 527 $7^{\mathrm{VP}}$. In Bergey's Manual of Systematic Bacteriology, 2nd edn, vol. 2, part C, pp. 757-759. Edited by D. J. Brenner, N. R. Krieg, J. T. Staley \& G. M. Garrity. New York: Springer.

Kelly, D. P. \& Wood, A. P. (2006). Thiomonas delicata comb. nov. In List of New Names and New Combinations Previously Effectively, but not Validly, Published, Validation List no. 109. Int J Syst Evol Microbiol 56, 925-927.

Kelly, D. P., Wood, A. P. \& Stackebrandt, E. (2005). Genus II. Thiobacillus Beijerinck $1904^{\mathrm{b}}, 597^{\mathrm{AL}}$. In Bergey's Manual of Systematic Bacteriology, 2nd edn, vol. 2, part C, pp. 764-769. Edited by D. J. Brenner, N. R. Krieg, J. T. Staley \& G. M. Garrity. New York: Springer.

Kimura, M. (1980). A simple method for estimating evolutionary rates of base substitutions through comparative studies of nucleotide sequences. J Mol Evol 16, 111-120.

Lane, D. J., Harrison, A. P., Jr, Stahl, D., Pace, B., Giovannoni, S. J., Olsen, G. J. \& Pace, N. R. (1992). Evolutionary relationships among sulfur- and iron-oxidizing eubacteria. J Bacteriol 174, 269-278.

London, J. (1963). Thiobacillus intermedius nov. sp., a novel type of facultative autotroph. Arch Mikrobiol 46, 329-337.
London, J. \& Rittenberg, S. C. (1967). Thiobacillus perometabolis nov. sp., a non-autotrophic thiobacillus. Arch Mikrobiol 59, 218-225.

Martinez-Murcia, A. J., Benlloch, S. \& Collins, M. D. (1992). Phylogenetic interrelationships of members of the genera Aeromonas and Plesiomonas as determined by $16 \mathrm{~S}$ ribosomal DNA sequencing: lack of congruence with results of DNA-DNA hybridizations. Int J Syst Bacteriol 42, 412-421.

Mizoguchi, T., Sato, T. \& Okabe, T. (1976). New sulfur-oxidizing bacteria capable of growing heterotrophically, Thiobacillus rubellus nov. sp. and Thiobacillus delicatus nov. sp. J Ferm Technol 54, 181-191.

Moreira, D. \& Amils, R. (1996). PCR-mediated detection of the chemolithotrophic bacterium Thiobacillus cuprinus using $23 \mathrm{~S}$ rDNAand 16S/23S intergenic spacer region-targeted oligonucleotide primers. FEMS Microbiol Lett 142, 289-293.

Moreira, D. \& Amils, R. (1997). Phylogeny of Thiobacillus cuprinus and other mixotrophic thiobacilli: proposal for Thiomonas gen. nov. Int J Syst Bacteriol 47, 522-528.

Selenska-Pobell, S., Otto, A. \& Kutschke, S. (1998). Identification and discrimination of thiobacilli using ARDREA, RAPD and rep-APD. J Appl Microbiol 84, 1085-1091.

Shooner, F., Bousquet, J. \& Tyagi, R. D. (1996). Isolation, phenotypic characterization, and phylogenetic position of a novel, facultatively autotrophic, moderately thermophilic bacterium, Thiobacillus thermosulfatus sp. nov. Int J Syst Bacteriol 46, 409-415.

Ulitzur, S. (1972). Rapid determination of DNA base composition by ultraviolet spectroscopy. Biochim Biophys Acta 272, 1-11. 